\title{
Overdrive suppression of implanted pacemakers in patients with $\mathrm{AV}$ block
}

\author{
HELGE GRENDAHL, MÅLFRID MILLER ${ }^{1}$, AND JOHN KJEKSHUS ${ }^{2}$
}

From Department VIII, Ullevål Hospital, Oslo, Norway

SUMMARY Patients being permanently paced for symptomatic AV block were studied by overdrive suppression of the QRS-inhibited pacemaker, in order to observe the underlying heart rhythm. The chest wall stimulation method was used.

In complete AV block the escape rhythm recovery time proved highly reproducible on repeated testing on the same day, and in many patients remained so over months or years. Occasionally, a doubling of the escape rhythm recovery time was seen, suggesting initial exit block of the escape focus. Resetting of the escape rhythm usually followed an exponential curve until stabilisation after about 3 minutes.

An early escape rhythm with a recovery time of less than 4 seconds was found on every occasion in 21 of 58 patients with complete AV block, and inconstantly in 23 more; in 14 it was never observed.

Accidental pacing failure was seen in 15 patients. The overdrive suppression test was helpful in selecting pacemaker dependent patients.

The sudden failure of an implanted pacemaker has serious consequences in patients whose underlying rhythm is inadequate. Overdrive suppression of QRS inhibited pacemakers permits pacing to be stopped briefly and safely to reveal this rhythm (Barold et al., 1970; Samet et al., 1970). The pulse generator may be inhibited by overdrive impulses from an external pacemaker, by passing a magnet over it (Thormann and Schwarz, 1975; Voukydis et al., 1975), or by the use of an electronic programmer or rate controller (Latif and Ewy, 1977). Repeated tests are of value in studying the progress of AV conduction disturbances.

The purpose of the present investigation was to study the usefulness of the overdrive suppression test at routine follow-up visits in a pacemaker clinic with respect to the distribution and progress of different grades of $\mathrm{AV}$ block and the various modes of escape rhythm in patients with complete AV block.

\section{Patients and methods}

Ninety-two patients ( 55 men, 37 women, average age 70 years) with QRS inhibited unipolar en-

${ }^{1}$ Present address: Institute for Experimental Medical Research, Ullevål Hospital, Oslo, Norway.

'Present address: Med.avd.B., Rikshospitalet, Oslo, Norway. Received for publication 18 July 1977 docardial pacemakers were followed for at least one year. Routine pacemaker control studies were undertaken three monthly, during which suppression of the implanted pacemaker was performed. The indication for pacing was syncope in 62 patients and symptomatic bradycardia in 30 . The aetiology of AV block was idiopathic in 55 cases, ischaemic in 23, and miscellaneous in 14 (aortic valvular disease, mitral valvular disease, rheumatoid arthritis, ankylosing spondylitis, temporal arteritis, and dystrophia myotonica). Thirty-five patients were taking no drugs regularly; 40 received maintenance doses of digitalis. The following pulse generators were in use: Medtronic 5843, 5943, 5945, 5961, 5951, Cordis Stanicor, Omni Stanicor, Elema 157, ELA Stanium, Stimulith.

The patients were examined in the supine position. The electrocardiogram (standard lead II) was displayed on an oscilloscope and recorded on paper at $25 \mathrm{~mm} / \mathrm{s}$. Impulses from an external constant current pacemaker, rate $120 / \mathrm{min}$, amplitude approximately $10 \mathrm{~mA}$, were applied with two skin electrodes across the implanted pulse generator to produce inhibition. In some patients this ? was repeated after an interval of at least one minute to observe the reproducibility of the escape rhythm. If no spontaneous rhythm appeared after $4 \mathrm{~s}$, or if the patients complained of dizziness, the test was stopped immediately. 
The underlying heart rhythm was observed for at least 3 minutes on several occasions in every patient in order to follow the resetting mechanism. Since $\mathrm{His}$ bundle recordings were performed in only a limited number of patients, the anatomical origin of their intrinsic rhythm when in complete AV block was uncertain and this rhythm is therefore referred to in general terms as the escape rhythm. A few patients were studied after different periods of overdrive ventricular pacing in order to observe the effect of pacing duration on the escape rhythm. Normally escape rhythm recovery time (ERRT), defined as the time interval from the beginning of the last paced QRS complex to the beginning of the first escape QRS complex, increased relative to the pacing duration up to 3 minutes. Accordingly, all escape rhythm recovery times stated are those obtained after more than 3 minutes of ventricular pacing. If after 4 seconds no escape rhythm occurred the overdrive suppression test was normally stopped. Occasionally, however, some patients developed an escape rhythm later. Escape rhythms with a recovery time of 4 seconds or less were defined as early escape rhythms in contrast to late escape rhythms with recovery times of more than this. Patients were grouped according to whether their escape rhythm recovery times were consistently, occasionally, or never, early.

\section{Results}

\section{DEGREE OF AV BLOCK}

In 58 patients complete $\mathrm{AV}$ block was observed (Table 1). Thirty-seven of these had complete block on all occasions. In 19, lower grades of AV block were also occasionally seen. Among the latter the degree of block increased during the observation period in 9 , decreased in 2 , and was inconsistent in the rest. The unpredictable nature of $\mathrm{AV}$ block is illustrated by 3 patients: in 2 sinus rhythm was seen after 2 years with constant complete AV block; in the other patient, complete AV block reappeared after 3 years of first degree block.

In 11 patients first degree block was the most advanced conduction disturbance seen at any of the studies, though all had originally had transient complete AV block, and 10 had had a history of Adams-Stokes attacks. Seven patients had sinus rhythm with normal $P Q$ intervals at each follow up study, all having had pacemakers initially implanted because of Adams-Stokes attacks.

When the underlying heart rhythm was followed for 3 minutes it was noted that atrioventricular conduction improved in some patients. In 3, complete AV block changed to $2: 1$ block after 15 , 18 , and 30 seconds, respectively, and in 4 patients there were alterations from $2: 1$ block to sinus rhythm after 9, 10,20, and 40 seconds, respectively. Some patients with complete AV block had escape rhythms with transient bundle-branch or bifascicular block which reverted after 5 to 10 seconds.

\section{ESCAPE RHYTHM RECOVERY TIME IN}

PATIENTS WITH COMPLETE AV BLOCK

Of 58 patients with permanent or intermittent complete AV block, 21 had a constant early escape rhythm (Table 2). Twenty-three patients had an inconstant early escape rhythm (Table 3); in these the incidence of early escape rhythm was unchanged during the observation period. Fourteen patients had no early escape rhythm (Table 4).

The escape rhythm recovery time was highly reproducible in repeated tests on the same day. In many patients it also varied very little over months or even years. Of the patients with a constant early escape rhythm, 55 per cent had an escape rhythm recovery time with a standard deviation of less than $300 \mathrm{~ms}$. In patients with an inconstant early escape rhythm the recovery time varied more, and only 13 per cent had a standard deviation less than $300 \mathrm{~ms}$.

Patients with a constant early escape rhythm showed a lower incidence of Adams-Stokes attacks $(43 \%)$ than those with an inconstant early escape rhythm $(65 \%)$ and those with no early escape rhythm (79\%) (Table 5). A maintenance dosage of digitalis had no consistent influence on the escape rhythm. No relation was seen between escape rhythm recovery time and QRS duration in the escape rhythm. The recovery time averaged 2347 ms in patients with a QRS duration less than

Table 192 patients treated with permanent pacing for symptomatic AV block. Grade of block observed during overdrive suppression of implanted pacemaker

\begin{tabular}{|c|c|c|c|c|c|}
\hline $\begin{array}{l}\text { Highest grade of } A V \text { block seen } \\
\text { (if any) }\end{array}$ & No. & $\begin{array}{l}\text { Lower gra } \\
\text { seen in sam } \\
\text { Grade } I I\end{array}$ & $\begin{array}{l}A V \text { bloch } \\
\text { ients } \\
\text { Grade I }\end{array}$ & $\begin{array}{l}\text { us rhythm occasionally } \\
\text { Sinus rhythm }\end{array}$ & $\begin{array}{l}\text { Patients with } \\
\text { occasional lower } \\
\text { grade } A V \text { block }\end{array}$ \\
\hline $\begin{array}{l}\text { Grade III } \\
\text { Grade II } \\
\text { Grade I } \\
\text { Sinus rhythm } \\
\text { Atrial fibrillation }\end{array}$ & $\begin{array}{r}58 \\
10 \\
11 \\
7 \\
6\end{array}$ & $\frac{16}{-}$ & $\begin{array}{r}4 \\
2 \\
- \\
-\end{array}$ & $\begin{array}{r}14 \\
5 \\
7 \\
- \\
-\end{array}$ & $\begin{array}{r}19 \\
6 \\
7 \\
- \\
\end{array}$ \\
\hline
\end{tabular}


Table 2 Escape rhythm recovery time in patients with constant early escape rhythm

\begin{tabular}{|c|c|c|c|c|}
\hline Case No. & $\begin{array}{l}\text { Observed time } \\
(m t h)\end{array}$ & $\begin{array}{l}\text { No. of controls with complete } \\
A V \text { block and escape rhythm } \\
\text { recovery time } \\
<4000 \mathrm{~ms}\end{array}$ & $\begin{array}{l}\text { Mean escape rhythm recovery } \\
\text { time (ms) }\end{array}$ & $\begin{array}{l}\text { No. of controls with lower grade } \\
A V \text { block or sinus rhythm }\end{array}$ \\
\hline $\begin{array}{l}1 \\
2^{\star} \\
3 \\
4 \\
5 \\
6 \dagger \\
7 \\
8 \\
9 \dagger \\
10 \\
11 \\
12 \dagger \\
13 \\
14 \\
15 \\
16 \\
17 \dagger \\
18 \\
19 \neq \\
20 \\
21\end{array}$ & $\begin{array}{l}30 \\
12 \\
38 \\
27 \\
27 \\
12 \\
34 \\
18 \\
12 \\
24 \\
24 \\
12 \\
36 \\
27 \\
32 \\
38 \\
12 \\
36 \\
38 \\
36 \\
36\end{array}$ & $\begin{array}{r}9 \\
4 \\
14 \\
5 \\
11 \\
1 \\
7 \\
7 \\
6 \\
10 \\
5 \\
5 \\
12 \\
7 \\
16 \\
10 \\
2 \\
1 \\
10 \\
3\end{array}$ & $\begin{array}{l}2230 \text {, SD } 680 \\
1815 \text {, SD } 60 \\
1597, \text { SD } 151 \\
2212, \text { SD } 1011 \\
1520, \text { SD } 186 \\
1680 \text { - } \\
2560, \text { SD } 526 \\
1955 \text {, SD } 538 \\
2285 \text {, SD } 409 \\
1558, \text { SD } 196 \\
2000 \text {, SD } 106 \\
1684, \text { SD } 61 \\
1626, \text { SD } 234 \\
2511, \text { SD } 621 \\
1592, \text { SD } 189 \\
2298, \text { SD } 261 \\
2070 \quad- \\
3740- \\
1623, \text { SD } 83 \\
2326, \text { SD } 652 \\
1662, \text { SD } 632\end{array}$ & $\begin{array}{r}0 \\
0 \\
0 \\
2 \\
0 \\
4 \\
3 \\
0 \\
0 \\
0 \\
0 \\
0 \\
0 \\
0 \\
5 \\
6 \\
7 \\
14 \\
1 \\
6 \\
6\end{array}$ \\
\hline
\end{tabular}

* Shift to asynchronous pacer

† Patient died

¥ Patient had accidental pacing failure

Table 3 Escape rhythm recovery time in patients with inconstant early escape rhythm

\begin{tabular}{|c|c|c|c|c|c|}
\hline Case No. & $\begin{array}{l}\text { Observed time } \\
\text { (mth) }\end{array}$ & $\begin{array}{l}\text { No. controls with complete } \\
\text { AV block and escape } \\
\text { rhythm recovery time } \\
<4000 \mathrm{~ms}\end{array}$ & $\begin{array}{l}\text { Mean escape rhythm } \\
\text { recovery time (ms) }\end{array}$ & $\begin{array}{l}\text { No. controls with complete } \\
\text { AV block and escape } \\
\text { rhythm recovery time } \\
>4000 \mathrm{~ms}\end{array}$ & $\begin{array}{l}\text { No. controls with lower } \\
\text { grade } A V \text { block or sinus } \\
\text { rhythm }\end{array}$ \\
\hline $\begin{array}{l}22 \\
23 \\
24 \star \ddagger \\
25 \\
26^{\star} \ddagger \\
27^{\star} \ddagger \\
28 \\
29 \\
30 \\
31 \dagger \\
32^{\star} \\
33 \\
34 \\
35^{\star} \\
36 \\
37 \\
38 \\
39 \\
40^{\star} \\
41 \\
42 \\
43 \\
44\end{array}$ & $\begin{array}{l}30 \\
26 \\
18 \\
22 \\
24 \\
26 \\
26 \\
26 \\
25 \\
15 \\
21 \\
20 \\
40 \\
26 \\
30 \\
33 \\
36 \\
36 \\
21 \\
20 \\
40 \\
24 \\
40\end{array}$ & $\begin{array}{r}10 \\
2 \\
1 \\
1 \\
6 \\
10 \\
3 \\
8 \\
1 \\
1 \\
5 \\
4 \\
1 \\
3 \\
8 \\
9 \\
4 \\
5 \\
2 \\
2 \\
21 \\
3 \\
5\end{array}$ & $\begin{array}{l}2167, \text { SD } 382 \\
3490- \\
2180- \\
1660- \\
1640, \text { SD } 118 \\
2134, \text { SD } 735 \\
1933, \text { SD } 321 \\
1753, \text { SD } 573 \\
2500 \quad- \\
2240 \text { - } \\
2532, \text { SD } 619 \\
2570, \text { SD } 399 \\
3400,- \\
2673, \text { SD } 745 \\
2646, \text { SD } 929 \\
1624, \text { SD } 227 \\
3215, \text { SD } 744 \\
2928, \text { SD } 725 \\
1580- \\
2150 \text { D } \\
2321, \text { SD } 462 \\
1973, \text { SD } 491 \\
2156, \text { SD } 922\end{array}$ & $\begin{array}{r}2 \\
6 \\
5 \\
1 \\
1 \\
2 \\
5 \\
1 \\
2 \\
2 \\
3 \\
5 \\
10 \\
6 \\
12 \\
3 \\
8 \\
12 \\
1 \\
13 \\
4 \\
2 \\
3\end{array}$ & $\begin{array}{l}0 \\
1 \\
0 \\
7 \\
0 \\
0 \\
0 \\
0 \\
6 \\
0 \\
0 \\
0 \\
0 \\
0 \\
0 \\
0 \\
0 \\
0 \\
0 \\
0 \\
0 \\
1 \\
4\end{array}$ \\
\hline
\end{tabular}

See Table 2 for key to footnotes.

$0 \cdot 10 \mathrm{~s}, 2074 \mathrm{~ms}$ in patients with a QRS duration of $0 \cdot 10$ to $0 \cdot 12 \mathrm{~s}$, and 2484 when the $\mathrm{QRS}$ duration was more than $0.12 \mathrm{~s}$.

His bundle potentials in 13 patients (Table 6) were not recorded simultaneously with the overdrive suppression tests. The majority of proximal AV blocks were seen in patients with constant early escape rhythm.
When the escape rhythm was followed for 3 minutes most patients showed a decrease in RR interval which followed an exponential curve (Fig. 1). However, in the first 5 to 10 seconds the $R R$ interval was often subject to large variation. After 2 to 3 minutes a stable RR interval was observed. Departures from this pattern were seen. A few patients had an exponential decrease in $\mathbf{R} R$ 
Table 4 Observations during overdrive suppression test in patients with no early escape rhythm

\begin{tabular}{llll}
\hline $\begin{array}{l}\text { Case } \\
\text { No. }\end{array}$ & $\begin{array}{l}\text { Observed } \\
\text { time } \\
\text { (mth) }\end{array}$ & $\begin{array}{l}\text { No. controls with } \\
\text { complete AV block } \\
\text { and escape rhythm } \\
\text { recovery time } \\
<4000 \text { ms }\end{array}$ & $\begin{array}{l}\text { No. controls with } \\
\text { lower grade } A V \text { block } \\
\text { or sinus rhythm }\end{array}$ \\
\hline $45 \ddagger$ & 29 & 6 & \\
46 & 36 & 15 & 1 \\
47 & 36 & 14 & 0 \\
$44^{\star} \ddagger$ & 13 & 4 & 0 \\
49 & 36 & 4 & 0 \\
$50^{\star}$ & 12 & 5 & 14 \\
$51 \dagger \ddagger$ & 14 & 6 & 0 \\
$52^{\star}$ & 12 & 2 & 0 \\
53 & 28 & 11 & 0 \\
54 & 36 & 1 & 0 \\
$55 \ddagger$ & 36 & 12 & 10 \\
$56 \star$ & 16 & 3 & 0 \\
$57 \ddagger$ & 30 & 7 & 3 \\
58 & 42 & 3 & 9 \\
\hline
\end{tabular}

See Table 2 for key to footnotes.

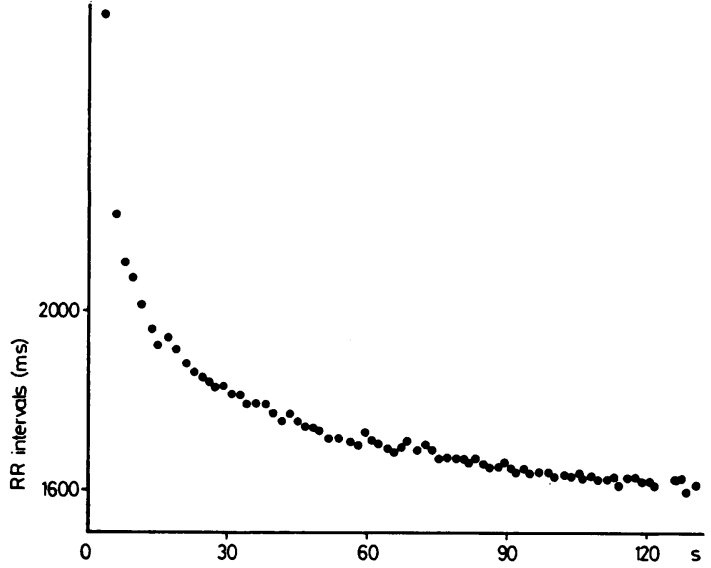

Fig. 1 Escape rhythm $R R$ intervals plotted against time in one patient (Case 21) with a constant early escape rhythm. Exponential RR interval decrease.

Table 5 Escape rhythm in patients with complete AV block: relation to previous Adams-Stokes attacks, oral digitalis, $Q R S$ duration of escape rhythm, and possible aetiology of $A V$ block

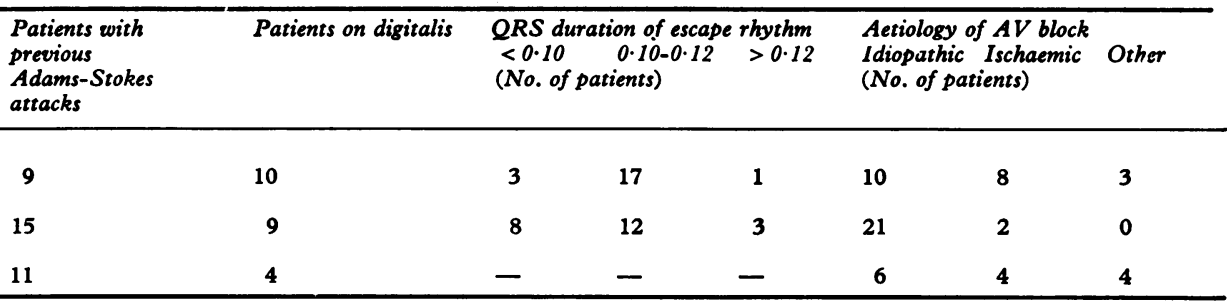

Table 6 Observations on bundle of His recordings and escape rhythm in patients with complete AV block

\begin{tabular}{|c|c|c|c|c|}
\hline $\begin{array}{l}\text { Tendency to } \\
\text { early escape rhythm }\end{array}$ & Case No. & $\begin{array}{l}\text { AV block on } \\
\text { His recording }\end{array}$ & $\begin{array}{l}\text { Mean escape rhythm } \\
\text { recovery time (ms) }\end{array}$ & $\underset{(s)}{Q R S \text { width of escape rhythm }}$ \\
\hline $\begin{array}{l}\text { Constant early } \\
\text { escape rhythm }\end{array}$ & $\begin{array}{l}1 \\
2 \\
3 \\
4 \\
5 \\
6 \\
7\end{array}$ & $\begin{array}{l}\text { Proximal } \\
\text { Proximal } \\
\text { Proximal } \\
\text { Proximal } \\
\text { Distal } \\
\text { Distal } \\
\text { Distal }\end{array}$ & $\begin{array}{l}2230 \text {, SD } 680 \\
1815 \text {, SD } 60 \\
1597 \text {, SD } 151 \\
2212 \text {, SD } 1010 \\
1520 \text {, SD } 186 \\
1680 \text { - } \\
2560 \text {, SD } 526\end{array}$ & $\begin{array}{r}0 \cdot 10-0 \cdot 12 \\
<0 \cdot 10 \\
0 \cdot 10-0 \cdot 12 \\
<0 \cdot 10 \\
0 \cdot 10-0 \cdot 12 \\
0 \cdot 10-0 \cdot 12 \\
0 \cdot 10-0 \cdot 12\end{array}$ \\
\hline $\begin{array}{l}\text { Inconstant early } \\
\text { escape rhythm }\end{array}$ & $\begin{array}{l}22 \\
23 \\
24 \\
25\end{array}$ & $\begin{array}{l}\text { Intra-Hisian } \\
\text { Intra-Hisian } \\
\text { Distal } \\
\text { Distal }\end{array}$ & $\begin{array}{l}2167, \text { SD } 382 \\
3490 \quad- \\
2180 \quad- \\
1660=\end{array}$ & $\begin{array}{r}0 \cdot 10-0 \cdot 12 \\
<0 \cdot 10 \\
0 \cdot 10-0 \cdot 12 \\
<0 \cdot 10\end{array}$ \\
\hline $\begin{array}{l}\text { No early } \\
\text { escape rhythm }\end{array}$ & $\begin{array}{l}45 \\
46\end{array}$ & $\begin{array}{l}\text { Proximal } \\
\text { Distal }\end{array}$ & - & - \\
\hline
\end{tabular}

interval which was prematurely terminated by a constant rate (Fig. 2); other patients had highly irregular RR intervals (Fig. 3).

The effect on escape rhythm recovery time of different durations of ventricular pacing was examined in a patients. In some of these patients a stepwise doubling of recovery time was recorded, with increasing pacing duration, probably owing to initial exit block (Fig. 4).

No serious complications were seen. Some patients with slow or absent escape rhythms found the test unpleasant, and in one, further tests were stopped for this reason. No episodes of ventricular tachycardia or ventricular fibrillation were observed. 


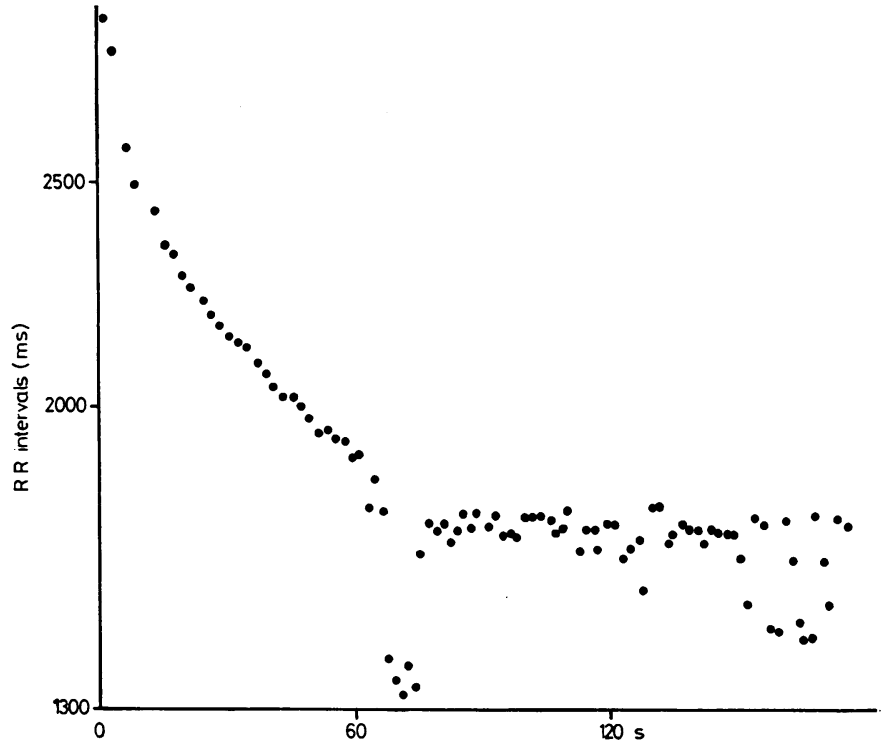

Fig. 2 Escape rhythm RR intervals plotted against time in one patient (Case 38) with an inconstant early escape rhythm. Exponential $R R$ interval decrease prematurely terminated by a constant rate.

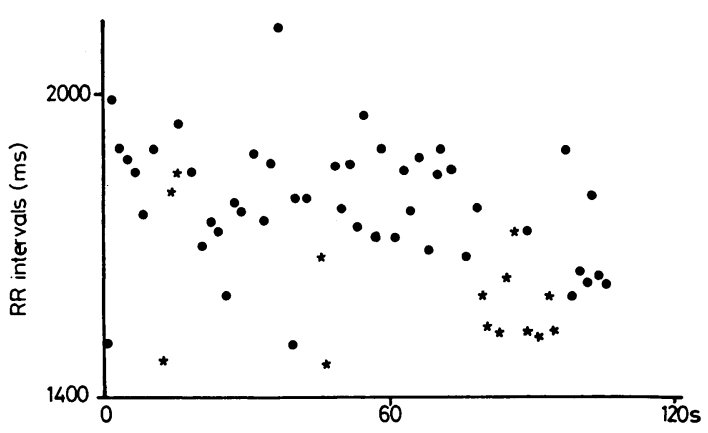

Fig. 3 Escape rhythm $R R$ intervals plotted against time in one patient (Case 22) with an inconstant early escape rhythm. Highly irregular rhythm.

(Two different $Q R S$ complexes indicated as dots and stars respectively.)

Failure to suppress the implanted pacemaker occurred, usually with totally hermetically enclosed pulse-generators (Stanium, Stimulith) or with some pacemakers that were under a thick layer of abdominal fat. Single pacer escapes with constant coupling to the previous QRS were often observed during suppression of Omni-Stanicor pacemakers, but only after the patients had developed their escape rhythm. The escape rhythm recovery time was not influenced.

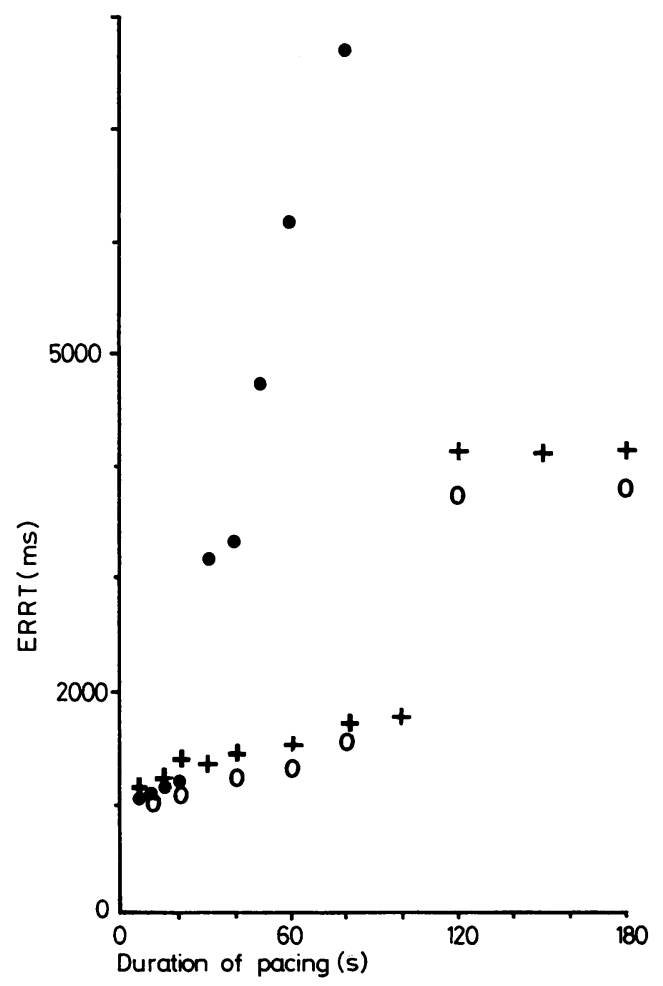

Fig. 4 Stepwise increase in escape rhythm recovery time related to increased duration of overdrive suppression pacing in 3 patients. 
Table 7 Observations during pacing failure

\begin{tabular}{rllll}
\hline Case No. & $\begin{array}{l}\text { Observations during } \\
\text { overdrive suppression test }\end{array}$ & $\begin{array}{l}\text { Cause for } \\
\text { pacing failure }\end{array}$ & Signs and symptoms during pacing failure \\
\hline 51 & AV III perm. & No escape rhythm & Battery & AV III. Irreg. escape rhythm; asystole; death \\
48 & AV III perm. No escape rhythm & Connector & AV III. Irreg. escape rhythm; syncope \\
57 & AV III int. & No escape rhythm & Battery & AV III. Irreg. escape rhythm; syncope \\
55 & AV III perm. No escape rhythm & Op. connector & AV III. Stable escape rhythm; no serious symptoms \\
45 & AV III int. & No escape rhythm & Battery & AV III. Stable escape rhythm; no serious symptoms \\
26 & AV III perm. Inconst. escape rhythm & Connector & AV III. Irreg. escape rhythm; syncope \\
27 & AV III perm. & Inconst. escape rhythm & $1:$ Exit & AV III. Stable escape rhythm; syncope before admission to hospital \\
& & $2:$ Battery & AV III. Stable escape rhythm; no serious symptoms \\
24 & AV III perm. Inconst. escape rhythm & Battery & AV III. Stable escape rhythm; no serious symptoms \\
19 & AV III perm. Const. escape rhythm & Connector & AV III. Stable escape rhythm; syncope before admission to hospital \\
59 & 2:1 AV int. & Connector & 2:1 AV block; syncope before admission to hospital \\
2 & AV II M.II & Battery & Sinus rhythm, no symptoms \\
59 & AV III Atr.fib. & At:Exit & Atrial fibrillation; no serious symptoms \\
& & $2:$ Connector & Atrial fibrillation; no serious symptoms \\
60 & AV I perm. & Connector & AV I; syncope before admission to hospital \\
61 & Sinus rhythm & Battery & Sinus rhythm; no symptoms \\
62 & Sinus rhythm & Battery & Sinus rhythm; no symptoms \\
\hline
\end{tabular}

Battery $=$ depletion. $\quad$ Connector $=$ loose connector or lead break. $\quad$ Exit $=$ Exit block.

CLINICAL OBSERVATIONS AFTER

\section{ACCIDENTAL PACING FAILURE}

Accidental pacing failure occurred in 15 patients (Table 7). Five of these had third degree AV block and no early escape rhythm; of these, one died in asystole while in hospital, another 2 had multiple Adams-Stokes attacks and emergency pacemaker replacement, while 2 had no serious symptoms and came to hospital in a stable escape rhythm. Three patients had permanent third degree AV block and an inconstant early escape rhythm; one had multiple syncopal attacks, another a single Adams-Stokes attack, and then stable escape rhythm, while the third had no serious symptoms. Only one patient with permanent complete AV block and a constant early escape rhythm had accidental pacing failure and he was admitted to hospital after a syncopal attack. Pacing failure in 3 patients with lower grades of AV block was associated with syncope in one, dizziness in one, and no symptoms in the third. Two patients in sinus rhythm had no symptoms and one patient with atrial fibrillation and complete AV block had symptomatic bradycardia, but no syncopal attacks.

Thus, some patients had Adams-Stokes attacks but others had no serious symptoms despite high grades of AV block and no early escape rhythm. On the other hand single Adams-Stokes attacks were experienced in patients with a constant early escape rhythm and in patients with lower grades of AV block. The latter group, however, had nonfunctioning pacemakers for a longer period before pacing failure was noticed.

Three sudden unwitnessed deaths occurred: 2 were in patients with consistent sinus rhythm, and 1 in a patient with intermittent complete AV block and no early escape rhythm.

\section{Discussion}

Overdrive suppression of implanted QRS-inhibited pacemakers has been introduced as a method of studying the underlying rhythm of paced patients and to select those who may be pacemaker dependent.

Based on this test the patients with complete AV block may be divided empirically into three clinical groups: patients with a constant early escape rhythm, an inconstant early escape rhythm, and with no early escape rhythm. In the latter category one fatality caused by proven asystole after accidental pacing failure was seen, and 2 more patients had multiple syncopal attacks, but 2 others arrived in hospital without serious symptoms. Patients with an inconstant early escape rhythm developed syncopal attacks after pacing failure in 2 out of 3 cases but even patients with a constant early escape rhythm had occasional syncope related to pacing failure. This is not surprising since the majority of these patients had Adams-Stokes attacks before permanent pacemaker implantation. Thus, our experience in 92 patients is that the overdrive suppression test is of clinical importance in the selection of pacemaker dependent patients.

Discrepancies between observations during the overdrive suppression test in the pacemaker clinic and observations during accidental pacing failure can probably be explained by the assumption that most episodes of accidental pacing failure develop gradually. In battery depletion the voltage will fall slowly, and for a short period borderline impulses will lead to intermittent pacing. Loss of contact related to breaks in wires or connections will probably also often initially be intermittent, with some impulses crossing high resistance fluid 
bridges. Thus, in effect, many such patients are weaned off artificial pacing, a situation in no way comparable to the abrupt cessation of pacing in a pacemaker clinic.

The escape rhythm recovery time was in most patients highly reproducible in repeated tests on the same day, and in many of those with a constant early escape rhythm it was remarkably stable for years. When the duration of overdrive ventricular pacing was increased the escape rhythm recovery time was prolonged, as a result of increased suppression of the intrinsic rhythm; occasionally, it was associated with a doubling or trebling of escape rhythm recovery time probably mediated by initial exit block of the escape focus. It has been observed by Langendorff and Pick (1971) and by Narula and Runge (1976) that the AV conduction in the His-Purkinje system can be influenced by overdrive suppression during artificial pacing, and exit block induced in this way may well explain the unpredictable variations in escape rhythm recovery time seen in many patients.

When the escape rhythm was recorded for 3 minutes, after initial irregular beats an exponential decrease in $R R$ interval was common, stabilisation occurring after about 3 minutes. This pattern of escape rhythm does not seem to have been described previously. Two phases are seen, the first a period of irregularity with a rapidly declining $R R$ interval for 10 seconds, and the second a stable monoexponential phase over the next 3 minutes. These two phases may indicate two different electrochemical mechanisms related to overdrive suppression of cardiac pacemaker cells, one fast and one slow.

It has been shown by Edhag and Rosén (1969) that an intravenous dosage of Lanatoside $\mathrm{C}$ depresses ventricular automaticity but in this study the group with a constant early escape rhythm contained the highest proportion of digitalised patients. Oral maintenance doses of digitalis seem to have no important effect on the escape rhythm recovery time.

Not unexpectedly, some relation was found between the location of AV block in bundle of His recordings and the tendency to early escape rhythm; for example, early escape rhythm was most frequent in patients with proximal AV blocks. A poor relation was seen between the $Q R S$ duration in the escape rhythm and the escape rhythm recovery time. One reason for this might be additional incomplete or complete bundle-branch block in the distal His-Purkinje system.

Occasionally ventricular fibrillation has been reported to follow severe bradycardia in patients with complete AV block, and Jensen et al. (1975) noted similar phenomena during threshold testing with Elema Vario pacemakers. The latter episodes may be related to subthreshold stimuli which arrive in the supernormal phase after a spontaneous escape beat, and thus to asynchronous pacing during magnet tests. No episodes of ventricular fibrillation were met with during the overdrive suppression test.

As a routine, implanted pacemakers were suppressed for only 4 seconds while awaiting the emergence of an escape rhythm. At times, however, this period was exceeded and escape rhythms with a later onset were seen which nevertheless became stable and adequate, particularly in patients with presumed initial exit block from the escape focus.

\section{Conclusion}

The overdrive suppression test of implanted QRSinhibited pacemakers can easily be used as a routine test in a pacemaker clinic, provided the electrocardiogram is adequately monitored. The underlying cardiac rhythm can be recorded and the progress of $\mathrm{AV}$ conduction disturbances observed with repeated tests. The overdrive suppression test is helpful in selecting patients prone to asystole or severe bradycardia after accidental pacing failure.

The escape rhythm recovery time is remarkably constant in many patients. Occasionally a doubling of escape rhythm recovery time can be observed. This may be the result of initial exit block from the escape rhythm focus. When the escape rhythm is recorded for 2 to 3 minutes an exponential decrease in $R R$ interval occurs after an initial irregular phase of 5 to 10 seconds. This may indicate that the effect of overdrive suppression of the permanent pacemaker on the escape focus is two different mechanisms, one fast and one slow. In a few patients other patterns of escape rhythm are seen. These patterns may be related to interference between nearby escape foci, to exit block, or to other unknown factors. The observations concerning the escape rhythm rate pattern have not apparently been previously published.

\section{References}

Barold, S. S., Pupillo, G. A., Gaidula, J. J., and Linhart, J. W. (1970). Chest wall stimulation in evaluation of patients with ventricular-inhibited demand pacemakers. British Heart fournal, 32, 783-789.

Edhag, O., and Rosen, A. (1969). The effect of lanatocide C on ventricular automaticity in man. Acta Medica Scandinavica, Suppl. 502, 93-96.

Jensen, G., Sigurd, B., and Sandøe, E. (1975). AdamsStokes seizures due to ventricular tachycardias in patients with heart block: prevalence and problems of management. Chest, 67, 43-48.

Langendorff, R., and Pick, A. (1971). Artificial pacing of the human heart. Its contribution to the understanding of the 
arrhythmias. American fournal of Cardiology, 28, 516-525. Latif, P., and Ewy, G. (1977). Temporary inhibition of permanently implanted demand pacemakers. Circulation, 55, 27-31.

Narula, O. S., and Runge, M. A. (1976). Accommodation of AV nodal conduction and fatigue phenomenon in the HisPurkinje system. In The Conduction System of the Heart, Structure, Function and Clinical Implications, pp 529-544. Ed. by $H$. J. J. Wellens, K. T. Lie, and M. J. Janse. H. E. Stenfert Kroese, Leiden.

Samet, P., Abbas, S. Z., Hildner, F. J., Javier, R. P., Befeler, B., and Schoenfeld, C. D. (1970). Effect of chest wall stimulation on cardiac pacemaker function. American Fournal of the Medical Sciences, 260, 285-298.
Thormann, J., and Schwarz, F. (1975). Störungen der Impulsangabe und temporäres abschalten implantierter Herzschrittmacher durch "Magnetwedeln" und durch elechtrische Brustwandstimulation. Herz Kreisl auf, 7, 348-353.

Voukydis, P. C., Shulman, A. N., and Cohen, S. I. (1975). Unmasking of slow intrinsic ventricular excitation by magnetic inhibition of $\mathbf{R}$ wave inhibited demand pacemakers. Chest, 67, 304-307.

Requests for reprints to Dr Helge Grendahl, Department VIII, Ullevål Hospital, Oslo, Norway. 